\title{
Study of radiation-resistant gel bases for composite detectors
}

\author{
A.Yu.Boyarintsev, N.Z.Galunov, N.L.Karavaeva, A.V.Krech, \\ I.V.Lazarev, L.G.Levchuk", T.A.Nepokupnaya, V.D.Panikarskaya, \\ V.F.Popov", P.V.Sorokin*, O.A. Tarasenko \\ Institute for Scintillation Materials, STC "Institute for Single Crystals", National \\ Academy of Sciences of Ukraine, 60 Lenin Ave., 61001 Kharkiv, Ukraine \\ "National Science Center "Kharkiv Institute of Physics and Technology", 1 \\ Akademicheskaya Str., 61108 Kharkiv, Ukraine
}

Received October, 7, 2013

\begin{abstract}
Light transmittance $T$ of the commercially available dielectric gels as a function of integrated radiation dose $D$ was studied in this work. Irradiation of samples was performed by electron accelerator with integrated radiation doses up to $90 \mathrm{Mrad}$. It allowed choosing the gels for development of radiation-resistant detection systems on their base. It was shown that dielectric gels Sylgard-184 and Sylgard-186 are the most suitable for this purpose due to their mechanical and optical characteristics.
\end{abstract}

Проведены результаты исследования оптического пропускания $T$ коммерчески-доступных диэлектрических гелей в зависимости от интегральной дозы облучения $D$. Облучение проводилось с помощью электронного ускорителя с интегральными дозами до 90 Мрад. Проведен отбор гелей для создания радиационно-стойких детектирующих систем на их основе. Показано, что по своим механическим и оптическим характеристикам наиболее перспективными являются диэлектрические гели Sylgard-184 и Sylgard-186.

Дослідження радіаційно-стійких гельових основ для композиційних детекторів. А.Ю.Болринцев, М.З.Галунов, Н.Л.Караваєва, А.В.Креч, І.В.Лазарєв, Л.Г.Левчук, Т.А.Непокупна, В.Д.Панікарська, В.Ф.Попов, П.В.Сорокін, О.А.Тарасенко.

Наведено результати дослідження оптичного пропускання $T$ комерційно-доступних діелектричних гелів залежно від інтегральної дози опромінення $D$. Опромінення проводилося за допомогою електронного прискорювача з інтегральними дозами до 90 Мрад. Проведено відбір гелів для створення радіаційно-стійких систем детектування на їх основі. Показано, що за своїми механічними і оптичними характеристиками найбільш перспективними є діелектричні гелі Sylgard-184 та Sylgard-186.

\section{Introduction}

Development of new scintillator materials, both in Ukraine and in the world becomes a very important problem. The high risk of exposure of ionizing radiations (especially neutron and alpha-particle radiations) on a human body needs the detection of low and super low fluxes of radiations. The detectors with large areas and high de- tection efficiency have to be used to increase the probability, and hence the stability of detection of ionizing radiation of low intensities. Such detectors must convert the particle energy stored in the detector material in light and then in the electric signal which is registered by a measuring unit. Recently, we proposed the production technology for the new type of scintillation materials, namely, composite scintillators 
[1-4]. They are obtained by introducing microcrystalline grains in non-scintillating gel base. It is possible to introduce both organic and inorganic microcrystalline grains. It was proved that these materials are the effective and selective detectors of fast and thermal neutrons, as well as of alpha particles. The proposed technology allows producing the detectors, which have no restrictions on the shape and area of an input window [1-4]. These scintillators and detectors on their base are characterized by versatility, are easy in use in the wide range of problems of detection and identification of ionizing radiations. These unique features of the composite scintillators make an attractive perspective of the development of radiation-resistant scintillation systems.

Application of the new class of accelerators, such as LHC CERN (Switzerland) caused dramatically increase of exposure intensity of the scintillation detectors. For example, scintillation detecting plates (tiles) are used for a frontal hadron collider (Hadron Endcap (HE)) in the CMS-detector (LHC CERN). Some tiles are located near the axis of a beam, where the intensity of the particles is large and therefore the exposure doses are large too. During 10 year operation of the CMS-detector the total dose ranges up to $10 \mathrm{Mrad}$ at the mean radiation dose rate of $1 \mathrm{Mrad} /$ year or $0.0001 \mathrm{Mrad} / \mathrm{h}$. Currently the experiments aimed at increasing the luminosity of the beam. This will lead to increase in radiation doses up to 30 Mrad.

Therefore, the increase of radiation hardness of scintillation materials is an object of intense interest. The first step to resolve this problem is to obtain information about radiation hardness of the potential materials as the bases of composite scintillators, namely, the commercially available dielectric gels are needed to create radiation-resistant detectors on their base. The paper is devoted to this problem, i.e. the study of radiation hardness of materials those can be the base for the composite scintillators.

\section{Experimental}

Selection of base material is an important task for creation of composite scintillators [5,6]. The criteria for selection of these bases are the following properties: inertness to crystalline grains, non-hygroscopicity, and high transparency of scintillation materials in the range of their luminescence during operation. We selected the following three samples manufactured by
Dow Corning Corporation (USA): Sylgard184, Sylgard-186, and Sylgard-527. The advantages of these dielectric silicone gels are the following: the maximum protection against moisture, wide range of operating temperatures, good adhesion to most materials, resistance to mechanical stresses and vibrations, absence of solvents. In addition to these materials, we also investigated the following dielectric gel bases: SKTN-med (viscosity of $20 \mathrm{P}$ ), SKTN-med (viscosity of $100 \mathrm{P}$ ), and SUREL-SL-1. SUREL-SL-1 is an optically transparent siloxane gel composition for scintillation techniques, medical instrumentations, the instrumentations for detection and analysis of ionizing radiations. SKTN-med is the polymer base of optically transparent gels with viscosity in the range from 2 to $1000 \mathrm{P}$, which are used in medical instruments. According to the chemical structure silicone rubbers have a special place among other rubbers of general and special purposes due to their unique properties. The most important of them it is a long-term preservation of elasticity in the broadest temperature range in comparison with all other elastomers. Siloxanes have the wide range of properties. It is high thermal stability in air and vacuum, biological inertness, wide range of operating temperatures, increased water repellency and resistance to water and water vapor, etc. Some characteristics of these materials are shown in Table 1.

We obtained $\varnothing 30 \mathrm{~mm} \times 5 \mathrm{~mm}^{3}$ samples using six selected gel bases, namely, Sylgard-184, Sylgard-186, Sylgard-527, SKTNmed $(20 \mathrm{P})$, SKTN-med $(100 \mathrm{P})$, and SUREL-SL-1. Due to fact that all the bases consist of two components, both components are mixed in the proportions shown in Table 1. We carried out vacuum treatment to remove air inclusions occurring during homogenization of samples. A liquid sample was filled into a mold and allowed to complete the polymerization process at the room temperature. After the polymerization, the preform was removed from the mold. After that, the special cliche were used to obtain the samples of dielectric gel material $30 \mathrm{~mm}$ in diameter. Such sample thickness was calculated from a value of volume of the primary liquid composition of the dielectric gel, which was filled into the mold. The gels Sylgard-527 and SUREL-SL-1 had sufficiently sticky gel-like consistency. Therefore, to avoid surface contamination of the samples, the mold before polymerization process was covered with a thin (less 
Table 1. Characteristics of two-component dielectric gels

\begin{tabular}{|c|c|c|c|c|c|c|}
\hline & $\begin{array}{c}\text { Sylgard-184 } \\
{[7]}\end{array}$ & $\begin{array}{c}\text { Sylgard-186 } \\
{[7]}\end{array}$ & $\begin{array}{c}\text { Sylgard-527 } \\
{[8]}\end{array}$ & $\begin{array}{l}\text { SKTN-med } \\
(20 \text { P) [9] }\end{array}$ & $\begin{array}{l}\text { SKTN-med } \\
(100 \mathrm{P})[9]\end{array}$ & $\begin{array}{c}\text { SUREL-SL-1 } \\
{[9]}\end{array}$ \\
\hline $\begin{array}{c}\text { Ratio of } \\
\text { components }\end{array}$ & $10: 1$ & $10: 1$ & $1: 1$ & $20: 1$ & $20: 1$ & $1: 1$ \\
\hline $\begin{array}{c}\text { Dynamic viscosity, } \\
\text { P }\end{array}$ & 35 & 65 & 4.75 & 20 & 100 & 20 \\
\hline $\begin{array}{l}\text { Heat conduction, } \\
\mathrm{W} /(\mathrm{m} \cdot \mathrm{K})\end{array}$ & 0.15 & - & 0.15 & - & - & - \\
\hline Colour & $\begin{array}{c}\text { Optically } \\
\text { transparent }\end{array}$ & $\begin{array}{c}\text { Optically } \\
\text { transparent }\end{array}$ & $\begin{array}{c}\text { Optically } \\
\text { transparent }\end{array}$ & $\begin{array}{c}\text { Optically } \\
\text { transparent }\end{array}$ & $\begin{array}{c}\text { Optically } \\
\text { transparent }\end{array}$ & $\begin{array}{c}\text { Optically } \\
\text { transparent }\end{array}$ \\
\hline $\begin{array}{c}\text { Operating } \\
\text { temperatures, }{ }^{\circ} \mathbf{C}\end{array}$ & $-55 \ldots+200$ & $-45 \ldots+200$ & $-55 \ldots+200$ & $-20 \ldots+150$ & $-20 \ldots+150$ & $-20+150$ \\
\hline Density, $\mathrm{g} / \mathrm{cm}^{3}$ & 1.04 & 1.12 & 0.97 & - & - & - \\
\hline \multirow[t]{4}{*}{ Hardening time } & $\begin{array}{l}10 \mathrm{~min} \\
\left(150^{\circ} \mathrm{C}\right)\end{array}$ & $\begin{array}{l}15 \min \\
\left(150^{\circ} \mathrm{C}\right)\end{array}$ & $\begin{array}{l}35 \mathrm{~min} \\
\left(150^{\circ} \mathrm{C}\right)\end{array}$ & \multirow[t]{4}{*}{$24 \mathrm{~h}\left(25^{\circ} \mathrm{C}\right)$} & \multirow[t]{4}{*}{$24 \mathrm{~h}\left(25^{\circ} \mathrm{C}\right)$} & \multirow[t]{4}{*}{$24 \mathrm{~h}\left(25^{\circ} \mathrm{C}\right)$} \\
\hline & $\begin{array}{l}20 \min \\
\left(125^{\circ} \mathrm{C}\right)\end{array}$ & - & $\begin{array}{l}75 \min \\
\left(125^{\circ} \mathrm{C}\right)\end{array}$ & & & \\
\hline & $\begin{array}{l}35 \min \\
\left(100^{\circ} \mathrm{C}\right)\end{array}$ & $\begin{array}{l}25 \min \\
\left(100^{\circ} \mathrm{C}\right)\end{array}$ & $\begin{array}{c}210 \min \\
\left(100^{\circ} \mathrm{C}\right)\end{array}$ & & & \\
\hline & $48 \mathrm{~h}\left(25^{\circ} \mathrm{C}\right)$ & $48 \mathrm{~h}\left(25^{\circ} \mathrm{C}\right)$ & - & & & \\
\hline $\begin{array}{c}\text { Dielectric } \\
\text { strength, } \mathrm{kV} / \mathrm{mm}\end{array}$ & 14 & - & 15.1 & $12 \ldots 15$ & $12 \ldots .15$ & - \\
\hline $\begin{array}{c}\text { Volume resistivity, } \\
\mathrm{Ohm} \cdot \mathrm{cm}\end{array}$ & $2.9 \cdot 10^{14}$ & - & $5.0 \cdot 10^{14}$ & - & - & - \\
\hline Refractive index & 1.41 & - & - & - & - & - \\
\hline
\end{tabular}

than $5 \mu \mathrm{m}$ ) polyethylene film. After the polymerization the same film was used for covering the second surface of the samples. Subsequently, all the studies of Sylgard-527 and SUREL-SL-1 gels were carried with this film. It should be noted that the presence of this film had no significant effect on the values of light transmittance of the samples. These values were within the range of the measurement error.

\section{Results and discussion}

The results of measurements of light transmittance $T$ for the above-mentioned types of dielectric gels are presented in this section. The samples were irradiated by electrons with accumulation of various integrated radiation doses $D$. For each type of the gel base a series of six samples was made, five of them were irradiated, and one of them was not irradiated and was used as a reference sample.

Measurements of light transmittance $T$ in the range from 300 to $700 \mathrm{~nm}$ were performed by Shimadzu-2450 spectrophotometer with the integrating sphere. The measurements were carried out concerning air (the comparison channel remained blank).
The value of light transmittance $T$ was calculated as follows:

$$
T=\frac{I}{I_{0}} \cdot 100 \%,
$$

where $I_{0}$ is the light flux falling on a sample, $I$ is the light flux passed through a sample.

The samples were irradiated by electron accelerator of the National Science Center "KIPT" with the electron energy about 9.2 $\mathrm{MeV}$ at the room temperature. During irradiation the radiation dose rate was uniform and was equal to $0.23 \pm 0.01 \mathrm{Mrad} / \mathrm{h}$. Inhomogeneity of irradiation of the samples did not exceed $5 \%$. All 6 types of samples were exposed to radiation at the same time. The samples were, consistently (by one sample of each type), exposed to radiation until accumulation of the necessary integrated radiation dose. To control radiation doses HARWELL Red 4034 plastic dosimeters with an accuracy of $\pm 10 \%$ were used.

The irradiation of the samples was not continuously in time, and with the pauses from $12 \mathrm{~h}$ to 3 days. The samples (by one of each type) accumulated the following values of $D: 8.63,19.1,33.1,43.0$, and 


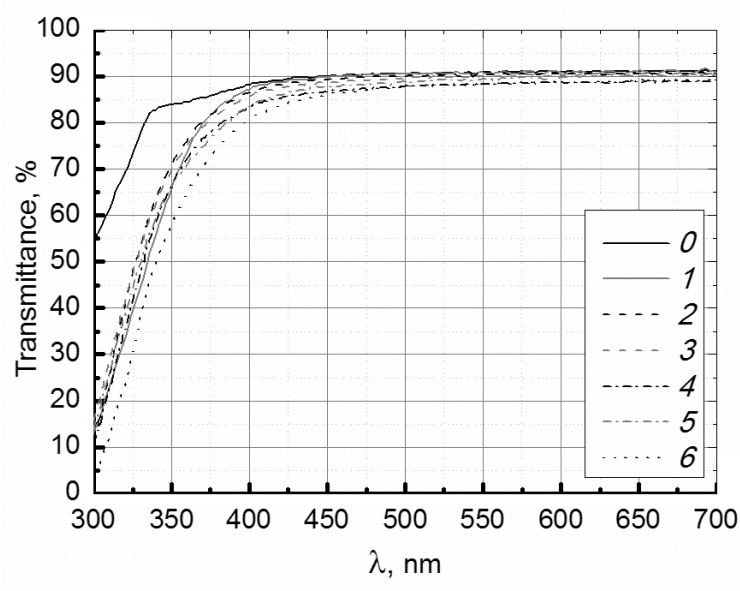

Fig. 1. Light transmittance $T$ in the wavelength range from 300 to $700 \mathrm{~nm}$ for a series of the samples of dielectric gel Sylgard-184 irradiated by different integrated exposure doses $D: 0-D=0$ (the reference sample), $1-D=8.63 \mathrm{Mrad}, 2-D=19.1 \mathrm{Mrad}$, $3-D=33.1 \mathrm{Mrad}, 4-D=43.0 \mathrm{Mrad}$, $5-D=50.7 \mathrm{Mrad}, 6-D=90.6 \mathrm{Mrad}$.

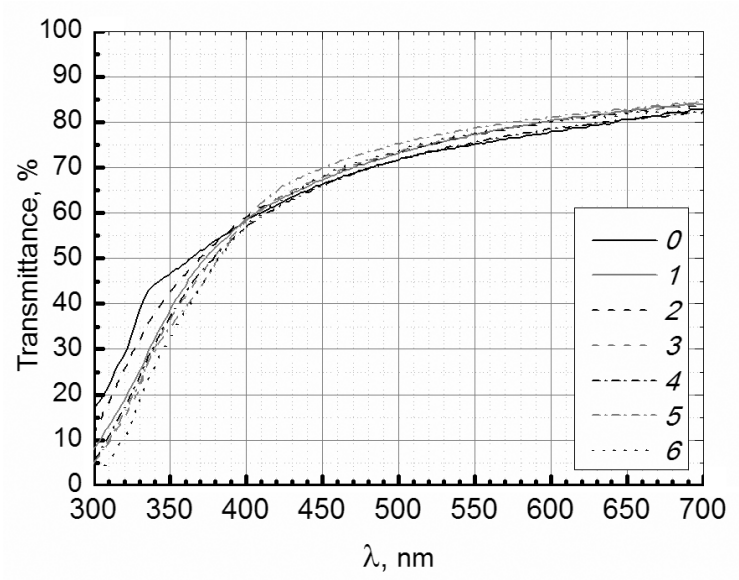

Fig. 2. Light transmittance $T$ in the wavelength range from 300 to $700 \mathrm{~nm}$ for a series of the samples of dielectric gel Sylgard-186 irradiated by different integrated exposure doses $D$. The notation is the same as in Fig. 1.

50.7 Mrad. The fifth samples $(D=$ $50.7 \mathrm{Mrad}$ ) of each type, first of all, were measured and after that were exposed to radiation up to $D=90.6 \mathrm{Mrad}$ and measured again.

For all types of the dielectric gels we used the reference non-irradiated samples $(D=0)$. Fig. 1 shows the values of light transmittance $T$ for a series of the samples of the gel base Sylgard-184. Fig. 1 demonstrates that the $T$-value slightly changes with increase in the radiation dose. It, in turn, testifies about the high radiation hardness of this dielectric gel. Fig. 2 dem-

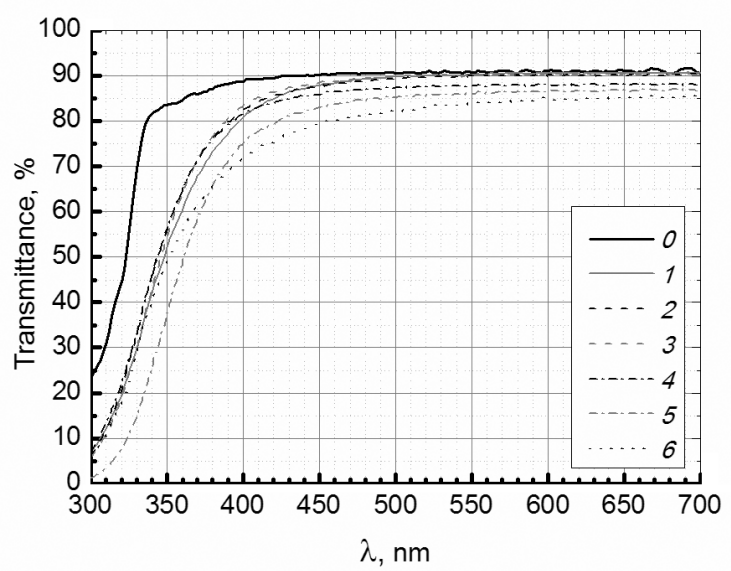

Fig. 3. Light transmittance $T$ in the wavelength range from 300 to $700 \mathrm{~nm}$ for a series of the samples of dielectric gel SKTN-med (20 P) irradiated by different integrated exposure doses $D$. The notation is the same as in Fig. 1.

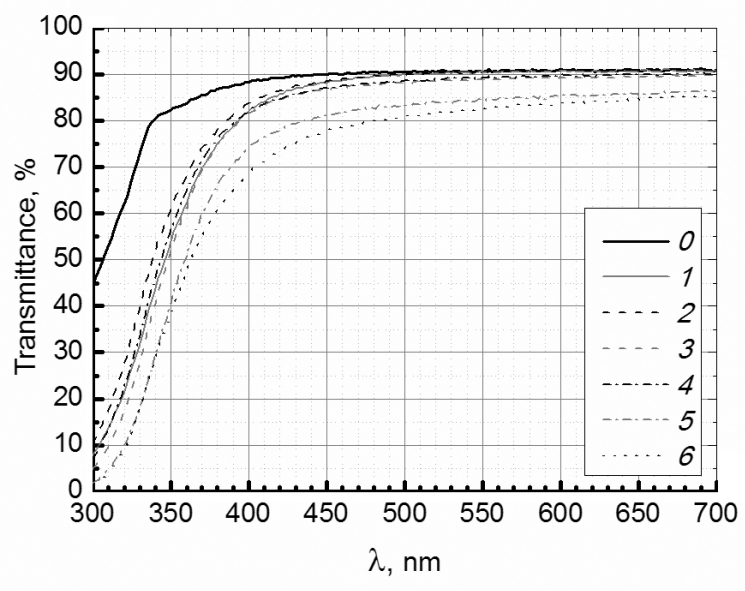

Fig. 4. Light transmittance $T$ in the wavelength range from 300 to $700 \mathrm{~nm}$ for a series of the samples of dielectric gel SKTN-med (100 P) irradiated by different integrated exposure doses $D$. The notation is the same as in Fig. 1.

onstrates the values of light transmittance $T$ for a series of the samples based on Sylgard-186. This dielectric gel also has high radiation hardness, while the $T$-values for $D=0$ (curve 0 ) are not too high.

Figs. 3 and 4 demonstrate light transmittance $T$ for series of the samples of SKTNmed $(20 \mathrm{P})$ and SKTN-med $(100 \mathrm{P})$, respectively. The $T$-values, practically, did not change with increase in the radiation dose. For $D=90.6$ Mrad (curve 6 in Figs. 3 and 4) for the wavelengths longer than $400 \mathrm{~nm}$ an inessential reduction of the $T$-values takes place. It did not exceeds $5 \%$. 


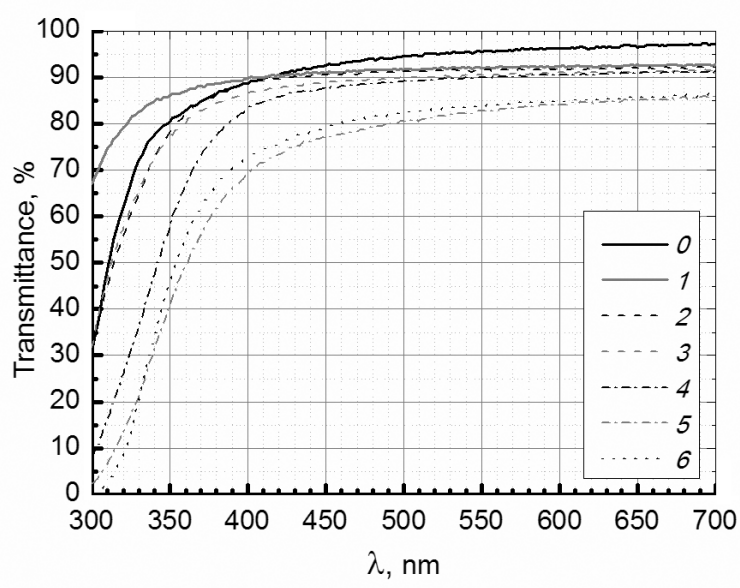

Fig. 5. Light transmittance $T$ in the wavelength range from 300 to $700 \mathrm{~nm}$ for a series of the samples of dielectric gel Sylgard-527 irradiated by different integrated exposure doses $D$. The notation is the same as in Fig. 1 .

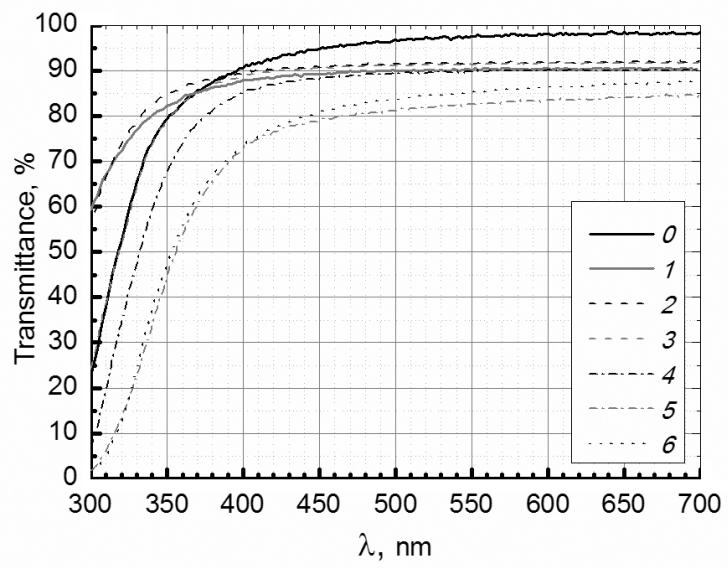

Fig. 6. Light transmittance $T$ in the wavelength range from 300 to $700 \mathrm{~nm}$ for a series of the samples of dielectric gel SUREL-SL-1 irradiated by different integrated exposure doses $D$. The notation is the same as in Fig. 1 .

Figs. 5 and 6 show the data of light transmittance $T$ for series of the samples of Sylgard-527 and SUREL-SL-1 dielectric gels. For these gels the dispersion of the $T$-values also did not exceed $5 \%$. It should be noted, that during irradiation all the samples of Sylgard-527 and SUREL-SL-1 became inelastic and fragile, and at the high doses of irradiation (50-90 Mrad) the samples sometimes cracked. Therefore the gel compositions Sylgard-527 and SUREL-SL-1 are not so good to be used as the bases for development of radiation-resistant scintillation systems.

\section{Conclusions}

The results of this work have indicated that optical properties of the studied industrial dielectric gels poorly vary as a function of the integrated radiation dose $D$ up to $90 \mathrm{Mrad}$. It is necessary to take into account the following. The dielectric gels can be used in the wide range of working temperatures, they do not chemically react with the materials used in scintillation technique, they are non-hygroscopic, and they possess high transparency in the range of luminescence of many scintillation materials. It allows claiming that application of the radiation-resistant like-gel dielectric bases is one of the promising ways for improving the characteristics of detecting devices.

Thus, the gels Sylgard-527 and SURELSL-1 could not be proposed as a base material for development of radiation-resistant scintillation systems due to degradation of their mechanical properties with increase of radiation dose. The dielectric gels Sylgard184 and Sylgard-186 are the most usable in the context of their mechanical and optical characteristics. Insignificant increase in light transmittance $T$ of some gels (SKTNmed (20 P), SKTN-med (100 P), Silgard527, and SUREL-SL-1) after irradiation by the radiation dose $D$ of 90.6 Mrad may be caused by the effect of partial solid-state recrystallization by the action of ionizing radiation. As it is known [10], the improvement of structure perfection can lead to reduction of probability of dispersion of light photons and to increase in transparency of the material. Determination of the dependence of optical characteristics of the dielectric gels as a function of radiation dose rate is the most important task of the next investigations.

Acknowledgements. This work was supported by the State Fund for Fundamental Research of Ukraine (project No.F58/06, "The effect of large radiation doses on scintillation and optical properties of novel types of organic detectors").

\section{References}

1. N.Z.Galunov, B.V.Grinyov, N.L.Karavaeva et al., IEEE Trans. Nucl.Sci., 56, 904 (2009).

2. N.Z.Galunov, B.V.Grinyov, N.L.Karavaeva et al., IEEE Trans. Nucl.Sci., 58, 339 (2011).

3. N.L.Karavaeva, O.A.Tarasenko, Functional Materials, 16, 92 (2009).

4. N.L.Karavaeva, O.A.Tarasenko, Functional Materials, 17, 379 (2010).

5. M.Schatz, Silikonovy Kaucuk, SNTL-Nakladatelstvi Technicke Literatury, Praha (1975) [in Czech]. 
6. L.A.Andryushchenko, B.V.Grinyov, Pribory $i$ Tekhnika Eksperimenta, No.4, 5 (1998).

7. Information about Dow Corning Brand Silicone Encapsulants: http://bdml.stanford.edu/ twiki/pub/Rise/PDMSProceSS/PDMSdatashe et.pdf.

8. OSTEK Materials, Dow Corning 527 silicone dielectric gel: http://www.ostec-materi- als.ru/materials/dow-corning-527silikonovyy -dielektricheskiy-gel.php.

9. http://www.surel.ru/about-us/index.php.

10. N.Z.Galunov, V.P.Seminozhenko, Teoriya i Primenenie Radioluminestsentsii Organicheskih Kondensirovannyh Sred, Naukova Dumka, Kiev (1997) [in Russian]. 